\title{
-675 4G/5G and -844 G/A of Plasminogne Activator Inhibitor-1 (Pai-1) Gene Polymorphisms and Type 2 Diabetes Mellitus in Tunisia: Case-Control Study
}

\author{
Mohamed Moustapha ${ }^{1 *}$, Molka Chadhli-Chaieb², Touhami Mahjoub3 ${ }^{3}$, Larbi Chaieb² \\ ${ }^{1}$ Internal Medicine Department, Hopital Cheikh Zayed, Nouakchott, Mauritania \\ ${ }^{2}$ Endocrinology Department, CHU Farhat Hachad, Sousse, Tunisia \\ ${ }^{3}$ Reserche Unit of Biology, Genetic of Cancer, Haematological and Autoimmune Disease, Monastir Faculty of Pharmacy, \\ Monastir, Tunisia \\ Email: *ouldhayani@gmail.com
}

How to cite this paper: Moustapha, M., Chadhli-Chaieb, M., Mahjoub, T. and Chaieb, L. (2019) $-6754 \mathrm{G} / 5 \mathrm{G}$ and $-844 \mathrm{G} / \mathrm{A}$ of Plasminogne Activator Inhibitor-1 (Pai-1) Gene Polymorphisms and Type 2 Diabetes Mellitus in Tunisia: Case-Control Study. Open Journal of Endocrine and Metabolic Diseases, 9, 75-83.

https://doi.org/10.4236/ojemd.2019.97008

Received: April 22, 2019

Accepted: July 27, 2019

Published: July 30, 2019

Copyright $\odot 2019$ by author(s) and Scientific Research Publishing Inc. This work is licensed under the Creative Commons Attribution International License (CC BY 4.0).

http://creativecommons.org/licenses/by/4.0/

\begin{abstract}
Background: The plasminogen activator inhibitor-1 (PAI-1) is a puissant antifibrinolytic factor; plasma PAI-1 level is high in type 2 diabetes. $4 \mathrm{G} / 5 \mathrm{G}$ polymorphism of PAI-1 gene is a major genetic determinant of plasma PAI-1 levels, with $4 \mathrm{G}$ carriers having high PAI-1 level than $5 \mathrm{G}$, theses pose the question about relation $\mathrm{T} 2$ patients and those polymorphisms. The aim of this study was to determine the relationship between the polymorphisms -675 4G/5G and -844 G/A of PAI-1 gene and type 2 diabetes mellitus. Methods: A case control study of 491 diabetic and 400 healthy controls. Genotyping of the polymorphism $-6754 \mathrm{G} / 5 \mathrm{G}$ was done by PCR-ASA (polymerase chain reaction, allele specific amplification), and the polymorphism $-844 \mathrm{G} / \mathrm{A}$ was done with PCR-RFLP (restriction fragment length polymorphism), the allelic frequency is calculated with hardy-Weinberg law, the statistic analysis was done by SPSS version 10. Results: Higher frequencies of The genotypes $4 \mathrm{G} / 4 \mathrm{G}$ ( $p=$ 0.01 ) and $4 \mathrm{G} / 5 \mathrm{G}$ of polymorphism $-6754 \mathrm{G} / 5 \mathrm{G}$ were seen in diabetic $(\mathrm{p}=$ $0.05)$ and higher frequencies of $5 \mathrm{G} / 5 \mathrm{G}$ was seen in controls $(\mathrm{p}<0.001)$. Higher frequencies of the genotype A/A $(p<0.01)$ and G/A $(p=N S)$ of polymorphism $-844 \mathrm{G} / \mathrm{A}$ was seen in diabetics and G/G was seen in controls ( $p$ $=0.01$ ). Conclusion: Our study found association between $4 \mathrm{G}$ allele of -675 $4 \mathrm{G} / 5 \mathrm{G}$ and A allele of $-844 \mathrm{G} / \mathrm{A}$ of PAI-1 gene and having type 2 diabetes mellitus in Tunisian population.
\end{abstract}

\section{Keywords}

Plasminogéne Activator Inhbitor-1 (PAI-1), -675 4G/5G Polymorphism, 
-844 G/A Polymorphism, Type 2 Diabetes Mellitus

\section{Introduction}

PAI-1 (plasminogen activator-inhibitor-1) is a powerful inhibitor of fibrinolysis. So it is a thrombogenic factor, it is incriminated in atherosclerosis [1] and vein thromboses or are high rate [2]. Type 2 diabetes is a disease with a very high cardiovascular risk [3] [4], where the level of PAI-1 Ag is increased [5]. This plasma level is determined by genetic polymorphisms [6] and environmental factors [7]. The elevation of plasma levels of PAI-1 during type 2 diabetes [7] [8] and the relationship between some polymorphisms of the PAI-1 gene and the plasma level of PAI-1 Ag raise the question of the possible association between these polymorphisms and type 2 diabetes (T2D).

\section{Patients and Methods}

This was a cross-sectional study, 491 type 2 diabetets patients and 400 healthy control was recruited after written consentement from endocrinology department at Farhat-Hachad hospital in Sousse-Tunisia, the study was approved by hospital ethic comity, inclusion criteria for patients was: known type 2 diabetes, exclusion criteria were: type 1 diabets, coagulation disorders, pregnancy, end stage chronic kidney disease, control are all clinically healthy personas who don't have chronic disease, all patients and contorls had clinical evaluation including (weight, high, BMI, Waist Circumference (WC)) and control had laboratory investigations include: Fasting blood glucose (FBG), Hb1 Ac, cholesterol, triglyceride, HDL-cholesterol), urea, creatinemia, FGR was calculated with cockroft formula, genetic study was done or all patients and control; -675 4G/5G. PAI-1 gene promoter polymorphism genotyping was done by PCR-ASA (allele specific amplification) and -844 G/A polymorphism genotyping was done by PCR-RFLP (restriction fragment length polymorphism), allelic frequency was calculated with hardy-Weinberg law, statistical analyses was performed using SPSS version 10.0 software.

\section{Results}

Our patients and controls are comparable in age and sex, with a sex ratio close to 1 in both cases, $74 \%$ of diabetic women and $76 \%$ of control women are postmenopausal. T2 diabetes patients have a significantly higher BMI. The control group has no metabolic abnormalities or impaired renal function. T2D have a significantly higher average total cholesterol, LDL-cholesterol, and triglycerides, and significantly lower mean HDL-cholesterol than controls, T2D had significantly higher urea and creatinine levels with clearance. Creatinine significantly lower, difference in serum uricemia is not significant (Table 1).

The Homozygous $4 \mathrm{G} / 4 \mathrm{G}$ and heterozygous $4 \mathrm{G} / 5 \mathrm{G}$ polymorphisms are significantly more common in T2D patients than in controls ( $16.7 \%$ and $49.1 \%$ versus 
Table 1. Clinicals and biologicals of T2D patients and controls.

\begin{tabular}{lccc}
\hline & Patients $\mathbf{n}=\mathbf{4 9 1}$ & Controls $\mathbf{n}=\mathbf{4 0 0}$ & $\mathbf{P}$ \\
\hline Age $($ Mean $\pm \mathrm{SD})$ & $58.32 \pm 10.5$ & $58.2 \pm 8.5$ & NS \\
Sex-ratio & 0.92 & 1.05 & NS \\
Menopause n $(\%)$ & $191(74.1)$ & $180(76)$ & NS \\
BMI & $27.5 \pm 5.4$ & $23.4 \pm 2.2$ & $<0.001$ \\
FBG $(\mathrm{mmol} / \mathrm{l})$ & $12.49 \pm 5.37$ & $5.1 \pm 0.6$ & $<0.001$ \\
Triglyceride $(\mathrm{mmol} / \mathrm{l})$ & $1.89 \pm 1.55$ & $1.16 \pm 0.56$ & $<0.001$ \\
Cholesterol $(\mathrm{mmol} / \mathrm{l})$ & $5.79 \pm 1.5$ & $4.6 \pm 1.23$ & $<0.001$ \\
HDL-CHT $(\mathrm{mmol} / \mathrm{l})$ & $0.96 \pm 0.24$ & $1.2 \pm 0.32$ & $<0.001$ \\
LDL-CHT $(\mathrm{mmol} / \mathrm{l})$ & $4.4 \pm 1.1$ & $2.5 \pm 1.66$ & $<0.001$ \\
Creatine $(\mu \mathrm{mol} / \mathrm{l})$ & $101.85 \pm 82$ & $82.8 \pm 26.8$ & $<0.001$ \\
\hline
\end{tabular}

$\mathrm{FBG}=$ fast blood glucose.

$9.5 \%$ and $39.8 \%$, respectively). Homozygous genotype $5 \mathrm{G} / 5 \mathrm{G}$ is significantly more common in controls (50.8\% versus $34.2 \%$ ), the $4 \mathrm{G}$ allele is significantly more common in T2D while the $5 \mathrm{G}$ allele is more common in controls (Table 2).

The homozygous A/A genotype is significantly more common in T2D than in controls (18.7\% versus 9.3\%). The heterozygous genotype G/A is also more common in T2D (47.9\% versus $44 \%$ ). $8 \%$ ), but the difference is not significant. The homozygous genotype G/G is significantly more common in controls $(46 \%$ versus $33.4 \%$ in T2D). Allele A is more common in T2D and the G allele is more frequent in controls $(\mathrm{p}<0.001)$ (Table 3$)$.

\section{Discussion}

PAI1 is the most powerful physiological inhibitor of fibrinolysis. PAI-1 is part of "serpins" and is also called serpin 1 [9].

The PAI-1 gene is located at chromosome 7, in position q 21.3-q 22 [6].

Approximately 100 polymorphisms of the PAI-1 gene are currently identified [10].

The most studied polymorphism is a deletion insertion of a $4 \mathrm{G}$ or $5 \mathrm{G}$ guanosine localized at $675 \mathrm{bp}$ (base pairs) upstream of the transcription start site $(-675)[11][12]$.

A second polymorphism at the promoter region of the PAI-1 gene is the G/A substitution at position -844 [12] [13].

The elevation of plasma PAI-1 Ag in type 2 diabetes is confirmed by most studies. Several studies have shown that the $4 \mathrm{G}$ allele of the $-6754 \mathrm{G} / 5 \mathrm{G}$ polymorphism is associated with a high level of PA-1 have also shown that this allele is associated with an android fat distribution, suggesting the possible involvement of this allele in susceptibility to type 2 diabetes.

Hoffestedt et al. [14] found that the RR of being obese in subjects with the $4 \mathrm{G}$ allele was 1.9 . 
Table 2. And alleles distribution of $-6754 \mathrm{G} / 5 \mathrm{G}$ polymorphism in T2D patients and controls.

\begin{tabular}{cccc}
\hline Génotyps n (\%) & T2D & Controls & p \\
\hline $4 \mathrm{G} / 4 \mathrm{G}$ & $82(16.7 \%)$ & $38(9.5 \%)$ & 0.001 \\
$4 \mathrm{G} / 5 \mathrm{G}$ & $241(49.1 \%)$ & $159(39.8 \%)$ & 0.005 \\
$5 \mathrm{G} / 5 \mathrm{G}$ & $168(34.2 \%)$ & $203(50.8 \%)$ & $<0.001$ \\
$4 \mathrm{G} / 5 \mathrm{G}$ alleles \% & $41.1 / 58.9$ & $29.4 / 70.6$ & $<0.001$ \\
\hline
\end{tabular}

Table 3. And alleles distribution of -844 G/A polymorphism in T2D patients and controls.

\begin{tabular}{cccc}
\hline Génotyps $\mathbf{n}(\%)$ & T2D & Controls & p \\
\hline A/A & $92(18.7 \%)$ & $37(9.3 \%)$ & $<0.001$ \\
G/A & $235(47.9 \%)$ & $179(44.8 \%)$ & $\mathrm{NS}$ \\
G/G & $164(33.4 \%)$ & $184(46 \%)$ & 0.001 \\
G/A alleles\% & $42.6 / 57.4$ & $31.6 / 68.4$ & $<0.001$ \\
\hline
\end{tabular}

The relationship between the $4 \mathrm{G}$ allele and obesity was observed in both sexes but was more pronounced in humans.

Lopes et al. [15] also found an association between 4G/5G polymorphism and obesity.

Mc Cormack [16] and Sartori et al. [17], Sola [18] found no relation between $4 \mathrm{G} / 5 \mathrm{G}$ polymorphism and obesity.

The authors of the Quebec Family Study [19] found an association between 4G/4G genotype and BMI, fat mass, hip circumference $(\mathrm{TH})$, total abdominal fat and subcutaneous abdominal fat, only in women.

Naran [20] found an association between 4G/4G genotype and high TT in white subjects.

Paradoxically, Van Hermelen et al. [21] found a higher BMI in subjects with genotype 5G/5G compared to genotype 4G/4G. However, they did not find any relationship between $4 \mathrm{G} / 5 \mathrm{G}$ polymorphism and TT/TH ratio, insulinemia, triglyceride levels, fat cell volume, PAI-1 adipose secretion, or plasma activity of PAI-1.

The association of the $-6754 \mathrm{G} / 5 \mathrm{G}$ polymorphism with type 2 diabetes has been the subject of several studies.

A recent metanalysis [22] of 14 studies (12 Asian studies, 2 studies of Caucasians) found a significant association between the $4 \mathrm{G}$ allele and type 2 diabetes, which is not significant for Caucasians.

A recent Malaysian study [23] found a significant association between the $4 \mathrm{G}$ allele and the prevalence of diabetes.

The Framingham Offspring Study [24] is a prospective study that included 2169 Caucasians., The authors did not find any relationship between this polymorphism and the incidence of type 2 diabetes or insulinoresistance markers.

Zietz [25], found a distribution of $4 \mathrm{G}$ and $5 \mathrm{G}$ alleles in diabetics close to that 
of the general population. Lopes et al. [15] found no significant difference in the distribution of genotypes and alleles of the $-6754 \mathrm{G} / 5 \mathrm{G}$ polymorphism between diabetics and non-diabetics.

Naran et al. [20] have similar results.

Broach [26] found a genotype frequency of $4 \mathrm{G} / 4 \mathrm{G}$ of $20.3 \%$, genotype $5 \mathrm{G} / 5 \mathrm{G}$ of $26.6 \%$ and genotype heterozygote $4 \mathrm{G} / 5 \mathrm{G}$ of $53.1 \%$, in 177 Caucasian Caucasian type 2 diabetics. Nagi [27] et al. comparable frequencies in diabetic Pimas Indians.

McCormack [16] and Mansfield [28] in their case-control studies found no differences in the frequencies of the different genotypes and alleles of the -675 $4 \mathrm{G} / 5 \mathrm{G}$ polymorphism between diabetics and non-diabetics.

An Austrian study found a significant relationship between the $4 \mathrm{G}$ allele and the discovery of gestational diabetes genotype $4 \mathrm{G} / 4 \mathrm{G}$ and maternal age emerged as two independent risk factors for gestational diabetes [29].

In our study, we found a significant difference in the distribution of different genotypes and alleles between diabetics and controls. The frequency of the $4 \mathrm{G}$ allele was significantly higher in diabetics compared to controls $(41.2 \%$ versus $29.4 \%)$. It was the same for the homozygous genotype $4 \mathrm{G} / 4 \mathrm{G}$ (16.7\% versus $9.5 \%)$.

The frequency of the $5 \mathrm{G}$ allele was higher in controls compared to diabetics. (70.7\% versus $58.7 \%)$. It was the same for the homozygous genotype $5 \mathrm{G} / 5 \mathrm{G}$ (50.8\% versus $34.2 \%)$.

Our results support an association between the $4 \mathrm{G}$ allele and type 2 diabetes. These results are in agreement with literature data in non-Caucasian populations and may be explained by the frequency of obesity and abnormalities. our group of diabetics. While our controls are free from obesity and metabolic abnormalities.

A Tunisian study [30] found a relationship between the $4 \mathrm{G}$ allele and diabetic retinopathy, which is consistent with findings from other studies [27] [31]. 2 other Tunisian studies found a relationship between this allele $4 \mathrm{G}$ and stroke [32] and MI [33].

The $-844 \mathrm{G} / \mathrm{A}$ polymorphism has been less studied in type 2 diabetics.

A Tunisian study found a relationship between the A allele and the IDM [33].

In the Lopes study [15], there was no significant difference in the distribution of the different genotypes and alleles of the $-844 \mathrm{G} / \mathrm{A}$ polymorphism between diabetics and non-diabetics, but they found that obese subjects carrying the genotype A/A had higher blood glucose and insulin levels than the $\mathrm{G}$ allele carriers.

A Mexican study of 100 children found an association between the A allele and the metabolic syndrome [34].

In our series, the prevalence of the homozygous A/A genotype was higher in diabetics compared to controls (18.7\% versus 9.3\%). It was the same with that of the allele A (42.6\% versus $31.7 \%)$. 
In controls, the homozygous genotype $\mathrm{G} / \mathrm{G}$ was more frequent (46\% versus $33.4 \%$ in diabetics) as well as the $\mathrm{G}$ allele (68.3\% versus $57.4 \%)$.

The strong points of our study: this is the first African study outside of South Africa that studied the relationship between these 2 polymorphisms and type 2 diabetes and the large size of our sample and the fact that it studied the polymorphism $-844 \mathrm{G} / \mathrm{A}$ rarely studied. But the study is limited by the transversal character as most studies, the realization of longitudinal studies with a large workforce is necessary to verify the role of these polymorphisms in the occurrence of diabetes type 2 .

\section{Conclusion}

Our work shows an association between the $4 \mathrm{G}$ polymorphism allele $-6754 \mathrm{G} / 5 \mathrm{G}$ and the A8 -844 G/A polymorphism allele of the PAI-1 gene and type 2 diabetes in the Tunisian population.

\section{Conflicts of Interest}

All authors declare no conflicts of interest.

\section{Author's Participation}

All authors had participated actively in manuscript realization.

\section{References}

[1] Kohler, H.P. and Grant, P.J. (2000) Plasminogen-Activator Inhibitor Type 1 and Coronary Artery Disease. The New England Journal of Medicine, 342, 1792-801. https://doi.org/10.1056/NEJM200006153422406

[2] Yasar Yildiz, S., Kuru, P., Toksoy Oner, E. and Agirbasli, M. (2014) Functional Stability of Plasminogen Activator Inhibitor-1. The Scientific World Journal, 2014, Article ID: 858293. https://doi.org/10.1155/2014/858293

[3] Grant, P.J. (2007) Diabetes Mellitus as a Prothrombotic Condition. Journal of Internal Medicine, 262, 157-172. https://doi.org/10.1111/j.1365-2796.2007.01824.x

[4] Beckman, J.A., Creager, M.A. and Libby, P. (2002) Diabetes and Atherosclerosis: Epidemiology, Pathophysiology, and Management. The Journal of the American Medical Association, 287, 2570-2581. https://doi.org/10.1001/jama.287.19.2570

[5] Juhan-Vague, I., Alessi, M.C. and Morange, P.E. (2000) Hypofibrinolysis and Increased PAI-1 Are Linked to Atherothrombosis via Insulin Resistance and Obesity. Annals of Medicine, 32, 78-84.

[6] Ding, J., et al. (2006) Plasminogen Activator Inhibitor Type 1 Gene Polymorphisms and Haplotypes Are Associated with Plasma Plasminogen Activator Inhibitor Type 1 Levels but Not with Myocardial Infarction or Stroke. American Heart Journal, 152, 1109-1115. https://doi.org/10.1016/j.ahj.2006.06.021

[7] Mansfield, M.W., Stickland, M.H. and Grant, P.J. (1995) Environmental and Genetic Factors in Relation to Elevated Circulating Levels of Plasminogen Activator Inhibitor-1 in Caucasian Patients with Non-Insulin-Dependent Diabetes Mellitus. Thrombosis and Haemostasis, 74, 842-847. https://doi.org/10.1055/s-0038-1649834

[8] De Taeye, B., Smith, L.H. and Vaughan, D.E. (2005) Plasminogen Activator In- 
hibitor-1: A Common Denominator in Obesity, Diabetes and Cardiovascular Disease. Current Opinion in Pharmacology, 5, 149-154.

https://doi.org/10.1016/j.coph.2005.01.007

[9] Morange, P.E., et al. (2007) Association of Plasminogen Activator Inhibitor (PAI)-1 (SERPINE1) SNPs with Myocardial Infarction, Plasma PAI-1, and Metabolic Parameters: The HIFMECH Study. Arteriosclerosis, Thrombosis, and Vascular Biology, 27, 2250-2257. https://doi.org/10.1161/ATVBAHA.107.149468

[10] Henry, M., et al. (1997) Five Frequent Polymorphisms of the PAI-1 Gene: Lack of Association between Genotypes, PAI Activity, and Triglyceride Levels in a Healthy Population. Arteriosclerosis, Thrombosis, and Vascular Biology, 17, 851-858. https://doi.org/10.1161/01.ATV.17.5.851

[11] Eriksson, P., Kallin, B., van't Hooft, F.M., Båvenholm, P. and Hamsten, A. (1995) Allele-Specific Increase in Basal Transcription of the Plasminogen-Activator Inhibitor 1 Gene Is Associated with Myocardial Infarction. Proceedings of the National Academy of Sciences of the United States of America, 92, 1851-1855.

https://doi.org/10.1073/pnas.92.6.1851

[12] Grubic, N., Stegnara, M., Peternel, P., Kaider, A. and Binder, B.R. (1996) A Novel G/A and the 4G/5G Polymorphism within the Promoter of the Plasminogen Activator Inhibitor-1 Gene in Patients with Deep Vein Thrombosis. Thrombosis Research, 84, 431-443. https://doi.org/10.1016/S0049-3848(96)00211-3

[13] Morange, P.E., et al. (2000) The A -844G Polymorphism in the PAI-1 Gene Is Associated with a Higher Risk of Venous Thrombosis in Factor V Leiden Carriers. Arteriosclerosis, Thrombosis, and Vascular Biology, 20, 1387-1391. https://doi.org/10.1161/01.ATV.20.5.1387

[14] Hoffstedt, J., Andersson, I.-L., Persson, L., Isaksson, B. and Arner, P. (2002) The Common-675 4G/5G Polymorphism in the Plasminogen Activator Inhibitor-1 Gene Is Strongly Associated with Obesity. Diabetologia, 45, 584-587. https://doi.org/10.1007/s00125-001-0774-5

[15] Lopes, C., Dina, C., Durand, E. and Froguel, P. (2003) PAI-1 Polymorphisms Modulate Phenotypes Associated with the Metabolic Syndrome in Obese and Diabetic Caucasian Population. Diabetologia, 46, 1284-1290. https://doi.org/10.1007/s00125-003-1170-0

[16] McCormack, L.J., et al. (1996) Promoter (4G/5G) Plasminogen Activator Inhibitor-1 Genotype in Pima Indians: Relationship to Plasminogen Activator Inhibitor-1 Levels and Features of the Insulin Resistance Syndrome. Diabetologia, 39, 1512-1518. https://doi.org/10.1007/s001250050606

[17] Sartori, M.T., et al. (2001) Role of the 4G/5G Polymorphism of PaI-1 Gene Promoter on PaI-1 Levels in Obese Patients: Influence of Fat Distribution and Insulin-Resistance. Thrombosis and Haemostasis, 86, 1161-1169. https://doi.org/10.1055/s-0037-1616045

[18] Sola, E., et al. (2008) Plasminogen Activator Inhibitor-1 Levels in Severe and Morbid Obesity. Effect of Weight Loss and Influence of 4G/5G Polymorphism. Thrombosis Research, 122, 320-327. https://doi.org/10.1016/j.thromres.2007.10.016

[19] Bouchard, L., Mauriège, P., Vohl, M.-C., Bouchard, C. and Pérusse, L. (2005) Plasminogen-Activator Inhibitor-1 Polymorphisms Are Associated with Obesity and Fat Distribution in the Quebec Family Study: Evidence of Interactions with Menopause. Menopause, 12, 136-143. https://doi.org/10.1097/00042192-200512020-00006

[20] Naran, N.H., Chetty, N. and Crowther, N.J. (2008) The Influence of Metabolic Syn- 
drome Components on Plasma PAI-1 Concentrations Is Modified by the PAI-1 4G/5G Genotype and Ethnicity. Atherosclerosis, 196, 155-163.

https://doi.org/10.1016/j.atherosclerosis.2007.03.024

[21] van Harmelen, V., Wahrenberg, H., Eriksson, P. and Arner, P. (2000) Role of Gender and Genetic Variance in Plasminogen Activator Inhibitor-1 Secretion from Human Adipose Tissue. Thrombosis and Haemostasis, 83, 304-308. https://doi.org/10.1055/s-0037-1613803

[22] Zhao, L. and Huang, P. (2013) Plasminogen Activator Inhibitor-1 4G/5G Polymorphism Is Associated with Type 2 Diabetes Risk. International Journal of Clinical and Experimental Medicine, 6, 632-640.

[23] Al-Hamodi, Z., Saif-Ali, R., Ismail, I.S., Ahmed, K.A. and Muniandy, S. (2012) Effect of Plasminogen Activator Inhibitor-1 and Tissue Plasminogen Activator Polymorphisms on Susceptibility to Type 2 Diabetes in Malaysian Subjects. Journal of Biomedicine and Biotechnology, 2012, Article ID: 234937.

https://doi.org/10.1155/2012/234937

[24] Meigs, J.B., et al. (2006) PAI-1 Gene 4G/5G Polymorphism and Risk of Type 2 Diabetes in a Population-Based Sample. Obesity (Silver Spring), 14, 753-758. https://doi.org/10.1038/oby.2006.85

[25] Zietz, B., Buechler, C., Drobnik, W., Herfarth, H., Schölmerich, J. and Schäffler, A. (2004) Allelic Frequency of the PAI-1 4G/5G Promoter Polymorphism in Patients with Type 2 Diabetes Mellitus and Lack of Association with PAI-1 Plasma Levels. Endocrine Research, 30, 443-453. https://doi.org/10.1081/ERC-200035728

[26] Broch, M., et al. (1998) Genetic Variation in Promoter (4G/5G) of Plasminogen Activator Inhibitor 1 Gene in Type 2 Diabetes. Absence of Relationship with Microangiopathy. Diabetes Care, 21, 463. https://doi.org/10.2337/diacare.21.3.463a

[27] Nagi, D.K., et al. (1997) Diabetic Retinopathy, Promoter (4G/5G) Polymorphism of PAI-1 Gene, and PAI-1 Activity in Pima Indians with Type 2 Diabetes. Diabetes Care, 20, 1304-1309. https://doi.org/10.2337/diacare.20.8.1304

[28] Mansfield, M.W., Stickland, M.H., Carter, A.M. and Grant, P.J. (1994) Polymorphisms of the Plasminogen Activator Inhibitor-1 Gene in Type1 and Type 2 Diabetes, and in Patients with Diabetic Retinopathy. Thrombosis and Haemostasis, 71, 731-736. https://doi.org/10.1055/s-0038-1642514

[29] Leipold, H., et al. (2006) Plasminogen Activator Inhibitor 1 Gene Polymorphism and Gestational Diabetes Mellitus. Obstetrics \& Gynecology, 10, 651-656.

https://doi.org/10.1097/01.AOG.0000199953.27961.f9

[30] Ezzidi, I., Mtiraoui, N., Chaieb, M., Kacem, M., Mahjoub, T. and Almawi, W.Y. (2009) Diabetic Retinopathy, PAI-1 4G/5G and -844G/A Polymorphisms, and Changes in Circulating PAI-1 Levels in Tunisian Type 2 Diabetes Patients. Diabetes \& Metabolism, 35, 214-219. https://doi.org/10.1016/j.diabet.2008.12.002

[31] Kimura, H., et al. (1998) Polymorphisms of Angiotensin Converting Enzyme and Plasminogen Activator Inhibitor-1 Genes in Diabetes and Macroangiopathy. Kidney International, 54, 1659-1669. https://doi.org/10.1046/j.1523-1755.1998.00139.x

[32] Saidi, S., Slamia, L.B., Mahjoub, T., Ammou, S.B. and Almawi, W.Y. (2007) Association of PAI-1 4G/5G and -844G/A Gene Polymorphism and Changes inPAI-1/tPA Levels in Stroke: A Case-Control Study. Journal of Stroke and Cerebrovascular Diseases, 16, 153-159. https://doi.org/10.1016/j.jstrokecerebrovasdis.2007.02.002

[33] Abboud, N., et al. (2010) Association of PAI-1 4G/5G and -844G/A Gene Polymorphisms and Changes in PAI-1/Tissue Plasminogen Activator Levels in Myocardial Infarction: A Case-Control Study. Genetic Testing and Molecular Biomarkers, 14, 23-27. https://doi.org/10.1089/gtmb.2009.0039 
[34] De la Cruz-Mosso, U., et al. (2012) Relationship of Metabolic Syndrome and Its Components with -844 G/A and HindIII C/G PAI-1 Gene Polymorphisms in Mexican Children. BMC Pediatrics, 12, 41. https://doi.org/10.1186/1471-2431-12-41 